\title{
Kombinirani kognitivno-bihevioralni i farmakološki tretman poslijeporođajne depresije - prikaz slučaja
}

1 Marta Gašparović

1 Klinika za psihijatriju, Klinički bolnički centar Osijek, Osijek

\section{Sažetak}

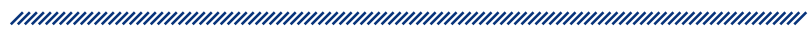

Među mentalnim poteškoćama u babinju po učestalosti i po kliničkom značaju ističe se poslijeporođajna depresija. Kognitivni model poslijeporođajne depresije naglašava ulogu specifičnih disfunkcionalnih majčinskih kognicija, sadržajno povezanih s nerealističnom idealizacijom majčinstva, majčinom samoefikasnošću i percepcijom od strane drugih. Uslijed stresora roditeljstva aktiviraju se nerealistična pravila i vjerovanja te dovode do pojave i održavanja simptoma depresije.

U radu je prikazana kognitivna konceptualizacija pacijentice koja je razvila poslijeporođajnu depresiju nakon rođenja prvog djeteta te terapija u trajanju od deset seansi vođena po načelima kognitivno-bihevioralne terapije, paralelno uz farmakoterapiju sertralinom.
Ključne riječi: poslijeporođajna depresija, kognitivno-bihevioralna terapija

Datum primitka: 03.03.2018.

Datum prihvaćanja: 20.03.2018.

DOI: $10.24141 / 1 / 4 / 1 / 7$

Adresa za dopisivanje:

Marta Gašparović

E-pošta: martadurkovic@yahoo.com

Tel.: 0915813961

Adresa: Klinika za psihijatriju KBC Osijek,

J. Huttlera 4, 31000 Osijek

\section{Uvod}

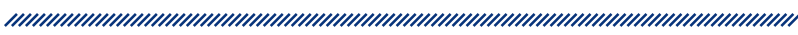

Vrijeme nakon rođenja djeteta razdoblje je vulnerabilnosti na mentalne poteškoće u žena, među kojima se po učestalosti i po kliničkom značaju ističe poslijeporođajna depresija. Njezina prevalencija procjenjuje se između 0,1 i 26,3 \% kada se određuje strukturiranim kliničkim intervjuom te između 2 i 80 \% kada se primjenjuju samoocjenski upitnici ${ }^{1}$. Poslijeporođajna odrednica depresivne epizode u literaturi se različito definira, od uže postavljene vremenske odrednice četiri tjedna nakon porođaja Američke psihijatrijske udruge ${ }^{2}$ do početka unutar godinu dana nakon porođaja ${ }^{3}$. Za postavljanje dijagnoze poslijeporođajne depresije sniženo 
raspoloženje ili gubitak interesa i ugode u aktivnostima moraju biti prisutni barem dva tjedna, uz poremećaj sna, apetita, gubitak energije, osjećaj krivnje i bezvrijednosti, smanjenu koncentraciju, misli o smrti i suicidu. S obzirom na gotovo redovitu pojavu narušenog sna, promjene apetita i umora u babinju, postavljanje dijagnoze može biti otežano ${ }^{4}$.

Poslijeporođajna depresija ne smatra se posebnim dijagnostičkim entitetom u odnosu na depresivne epizode u bilo kojem drugom životnom razdoblju, no ipak ima svoja jedinstvena obilježja. Tako u kliničkoj slici mogu biti izraženiji anksioznost, psihomotorički simptomi (nemir ili agitacija) te poteškoće u donošenju odluka ${ }^{5,6}$. Osim toga, specifična je i po kontekstu u kojemu se javlja, jer babinje predstavlja razdoblje pojačanih prilagodbenih napora na novu životnu ulogu i velikih fizioloških promjena. Nadalje, ima i specifične negativne posljedice, jer osim što može utjecati na općenito funkcioniranje žene sa suicidom kao najtežim ishodom, utječe i na njezina roditeljska ponašanja te na razvoj odnosa majke i djeteta, što može imati dalekosežne posljedice na kognitivni, bihevioralni i emocionalni razvoj djeteta ${ }^{7}$.

Kao rizični čimbenici za poslijeporođajnu depresiju u literaturi se navode prijašnje epizode depresije te depresivni i anksiozni poremećaj u trudnoći, potom prijašnja predmenstrualna disforija, medicinske komplikacije porođaja, stresni životni događaji u trudnoći i ranom puerperiju, negativan stav prema trudnoći, slaba socijalna podrška, bračni konflikti, niski prihodi, imigrantski status i niži stupanj edukacije ${ }^{4,8}$.

$\mathrm{U}$ tretmanu poslijeporođajne depresije primjenjuju se antidepresivi kao i u drugim depresivnim poremećajima, no njihova primjena može biti otežana zbog izlučivanja lijekova u mlijeko i mogućega štetnog utjecaja na dojenče. Istraživanja o preferencijama žena o željenom vidu pomoći pokazala su da preferiraju neki od vidova terapije razgovorom s osobom koja ih ne osuđuje 9 . Prema nekim autorima, psihoterapija može biti prva linija izbora za žene s umjerenom do blagom poslijeporođajnom depresijom, dok se za umjerenu do tešku sliku preporučuju antidepresivi u kombinaciji s psihoterapijom $^{10}$, iako rezultati studija o koristi kombinirane primjene antidepresiva i psihoterapije nisu jednoznačni ${ }^{11}$. Od psihosocijalnih intervencija učinkovitost su pokazale interpersonalna psihoterapija, kognitivno-bihevioralna terapija, psihodinamička psihoterapija te suportivne intervencije kao što su telefonska podrška drugih majki, savjetovanje sa zdravstvenim stručnjakom ili podrška partnera ${ }^{11}$. Kognitivno-bihevioralna terapija pokazala se kao učinkovit tretman poslijeporođajne depresije, u klasičnom obliku i putem kognitivno-bihevioralnih intervencija preko interneta ${ }^{4,12,13}$.

Kognitivni tretman depresije temelji se na Beckovu kognitivnom modelu, prema kojemu disfunkcionalne (rigidne, ekstremne) kognitivne sheme osobu čine vulnerabilnom na specifične životne događaje kongruentne s važnim komponentama tih shema. Pojava takvih događaja dovodi do negativnih automatskih misli te do ponašajnih, emocionalnih i fizičkih simptoma depresije ${ }^{14}$. U poslijeporođajnoj depresiji osim općenitih disfunkcionalnih kognicija postoje i specifične disfunkcionalne kognicije sadržajno povezane s majčinstvom, koje ženu čine vulnerabilnom na razvoj depresije uslijed događaja specifičnih za roditeljstvo. Ovakve kognicije proizlaze iz maladaptivnih stavova o majčinstvu, koji mogu biti prisutni i godinama prije rođenja djeteta bez većeg učinka na psihičko funkcioniranje žene, no nakon rođenja djeteta mogu biti prediktivni za pojavu depresivnih i anksioznih simptoma ${ }^{15}$.

Sockol i suradnici opisuju tri teme maladaptivnih stavova o majčinstvu: vjerovanja o tuđoj prosudbi (npr. Ako moje dijete plače, ljudi će misliti da se ne znam pravilno pobrinuti za njega.), vjerovanja o majčinskoj odgovornosti (npr. Ako volim svoje dijete, moram željeti stalno biti uz njega.) te vjerovanja povezana s idealizacijom majčinske uloge (npr. Pogrešno je ako sam razočarana majčinstvom. $)^{15}$. O'Mahen i suradnici na uzorku depresivnih žena u perinatalnom periodu također opisuju tipične kognitivne teme: neispunjena visoka očekivanja od majčinstva, tumačenje nesklada između očekivanja i realiteta kao dokaz za vlastitu neadekvatnost kao majke, misli o pretjeranoj odgovornosti za dijete, vjerovanje da je majčinstvo zamijenilo sve druge osobne potrebe i htijenja te sklonost repetitivnim mislima o vlastitim poteškoćama (ruminacije) ${ }^{16}$. Zanimljivo je da zdrave majke također opisuju nerealistična i perfekcionistička očekivanja od majčinstva te intruzivne negativne misli povezane s djetetom, što dovodi do zaključka da su takve kognicije raspoređene na kontinuumu, uz jaču izraženost u depresivnoj nego u nedepresivnoj populaciji ${ }^{17}$.

Bihevioralni modeli depresije naglašavaju redukciju nagrađujućih ponašanja, nedostatak samonagrađivanja, samokažnjavajuće ponašanje, deficit vještina, nedostatak asertivnosti, slabe vještine rješavanja problema, izloženost averzivnim situacijama, deprivaciju sna te nedosljednost između ponašanja i posljedica ${ }^{18}$. Poslijeporođajno razdoblje donosi jedinstveni kontekst životnih okolnosti koje mogu negativno utjecati na mogućnost žene da se uključi u aktivnosti koje donose ugodu ili postignuće uslijed smanjenja razine fizičke 
aktivnosti, gubitka slobodnog vremena, povećanja opsega repetitivnih rutinskih aktivnosti, isključenosti iz dosadašnjih socijalnih krugova te isključenosti iz radne aktivnosti, uz onemogućen san, smanjenje razine kontrole nad događajima, gubitak autonomije te promjenu u izgledu i seksualnosti ${ }^{16,19}$.

Terapijske intervencije u kognitivno-bihevioralnom tretmanu depresije možemo podijeliti na kognitivne strategije usmjerene na edukaciju i kognitivno restrukturiranje (identificiranje i modificiranje disfunkcionalnih kognicija) te bihevioralne strategije planiranja aktivnosti, samonagrađivanja, treninga rješavanja problema te treninga asertivnosti i socijalnih vještina ${ }^{18}$. Za optimiziranje ishoda u tretmanu poslijeporođajne depresije može pomoći modifikacija navedenih tehnika prema specifičnim potrebama žena u babinju. U navedenoj studiji O'Mahen i suradnika izdvojene su strategije koje žene s poslijeporođajnom depresijom drže korisnima za ublažavanje simptoma: prepoznavanje da je razdoblje kroz koje prolaze vremenski ograničeno, normaliziranje poteškoća koje donosi majčinstvo, distrakcije, usporedba s majkama koje se lošije snalaze te poboljšanje socijalne podrške u praktičnom i emocionalnom vidu. Autori predlažu intervencije restrukturiranja nerealističnih vjerovanja o majčinstvu, normalizaciju poteškoća koje ono donosi, restrukturiranje vjerovanja o samožrtvovanju kroz prihvaćanje vlastitih potreba te smanjenje percepcije sukoba između vlastitih i djetetovih potreba, potom trening vještine upravljanja vremenom i vještine rješavanja problema te poticanje na komunikaciju i traženje socijalne podrške ${ }^{16}$.

\section{Povijest slučaja}

Opće informacije: Pacijentica ima 30 godina, udana je, po zanimanju diplomirana ekonomistica, zaposlena u uredu, prije dva mjeseca rodila je sina. Odrasla je u primarnoj obitelji, ima sestru. Odnose u obitelji opisuje kao uglavnom skladne i podržavajuće. Redovito je završila školovanje, zadnjih nekoliko godina radi na aktualnom mjestu $\mathrm{i}$ uglavnom je zadovoljna njime. U braku je tri godine, trudnoću je planirala, sa suprugom se dobro slaže. Do sada nije teže bolovala. Dala je usmeni pristanak za objavu.

Glavna pritužba: Od rođenja djeteta osjeća se sve lošije, tužna je, osjeća se prazno, plače, misli da je loša maj- ka, zbog čega ima osjećaj krivnje, nema volje da ujutro ustane, vrlo se malo bavi djetetom, zapušta higijenu, nije u kontaktu s prijateljima.

Povijesni razvoj problema: Još u trudnoći često je čitala članke na internetu o majčinstvu i odlučila da će svakako dojiti što duže. Opisuje da je očekivala sreću i zadovoljstvo nakon rođenja djeteta. Porođaj je protekao uredno, no sin je za nekoliko dana dobio žuticu, zbog čega je bila jako zabrinuta. Dobila je donekle neusklađene upute od liječnice i patronažne sestre kada i koliko da doji. Postala je preokupirana dojenjem na zahtjev djeteta, nije se odvajala od sina ni na kratko vrijeme. Noću je zbog učestalog dojenja sve manje spavala te je postala umorna i usporena, nije se mogla koncentrirati. Postala je potištena i plačljiva. Dječak je često plakao, zbog čega je mislila da je nesposobna majka. Ponekad bi pomislila da bi bilo bolje da nije rodila jer nije sposobna za brigu o djetetu, uz jaku krivnju. Počela je izbjegavati kontakt $\mathrm{s}$ djetetom, dane je provodila pasivno ležeći u krevetu, ruminirajući o svojem stanju, uvjerena da joj nikada neće biti bolje. Prestala je dojiti. Brigu o bebi preuzele su majka i svekrva pacijentice, što je u njoj produbilo krivnju i stid zbog njezina stanja.

Mentalni status pri dolasku: Bila je blaže zapuštene vanjštine, psihomotorički usporena, pognutog stava, hipomimična, usporenoga misaonog tijeka, oskudne spontane verbalizacije, iznosila je samokritična i pesimistična promišljanja, bila je znatno sniženog raspoloženja i voljnonagonskih dinamizama, no nije imala suicidalnih promišljanja ni planova.

\section{Formulacija slučaja}

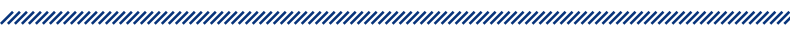

Presjek tipičnih trenutačnih kognicija i ponašanja: U tablici 1 prikazane su neke aktivirajuće situacije, uz tipične automatske misli, emocije i ponašanja.

Longitudinalni pogled na kognicije i ponašanja: Prije rođenja vlastitog djeteta pacijentica je imala malo doticaja s roditeljskim iskustvima te je formirala nerealna očekivanja od majčinstva kroz slike iz medija, ali i kroz navode vlastite majke da je svoju djecu odgajala sama i bez tuđe pomoći. Identificirana su disfunkcionalna pravila: „Majčinstvo bi trebalo stalno biti ugodno”, ,Majka mora sve svoje vrijeme i energiju posvetiti djetetu”, ,Majka 


\begin{tabular}{|c|c|c|c|c|}
\hline \multicolumn{5}{|c|}{ Tablica 1. Presjek trenutačnih kognicija i ponašanja } \\
\hline $\begin{array}{c}\text { Aktivirajuće } \\
\text { situacije }\end{array}$ & $\begin{array}{c}\text { Tipične automatske } \\
\text { misli }\end{array}$ & Značenje misli & Emocije & Ponašanje \\
\hline $\begin{array}{c}\text { Sin joj se nasmije, ona } \\
\text { pri tome ne osjeća } \\
\text { zadovoljstvo. }\end{array}$ & $\begin{array}{c}\text { Smije mi se, a ja ništa } \\
\text { ne osjećam. Trebala } \\
\text { bih biti sretna. Ja sam } \\
\text { čudovište. }\end{array}$ & $\begin{array}{c}\text { Nisam normalna } \\
\text { majka. }\end{array}$ & Tuga i krivnja & Povlačenje od djeteta \\
\hline $\begin{array}{c}\text { Razgovara s } \\
\text { prijateljicom koja } \\
\text { također ima malo } \\
\text { dijete. }\end{array}$ & $\begin{array}{c}\text { Ona je tako vesela, } \\
\text { sigurno je bolja mama } \\
\text { od mene, njoj to } \\
\text { polazi za rukom bez } \\
\text { problema. }\end{array}$ & $\begin{array}{c}\text { Druge su majke } \\
\text { uspješnije. }\end{array}$ & Tuga, razočaranje & $\begin{array}{c}\text { Sve rjeđe naziva } \\
\text { prijateljicu ine javlja } \\
\text { joj ne telefonske } \\
\text { pozive. }\end{array}$ \\
\hline $\begin{array}{c}\text { Provodi vrijeme sama } \\
\text { sa sinom, koji je } \\
\text { nervozan i plače. }\end{array}$ & $\begin{array}{c}\text { Nešto radim krivo jer } \\
\text { maleni plače, moram } \\
\text { ga umiriti, a ne znam } \\
\text { kako. }\end{array}$ & $\begin{array}{c}\text { Nisam kompetentna } \\
\text { majka. }\end{array}$ & Ljutnja, anksioznost & $\begin{array}{c}\text { Zove telefonom } \\
\text { supruga da se odmah } \\
\text { vrati kući i preuzme } \\
\text { sina. }\end{array}$ \\
\hline
\end{tabular}

je isključivo odgovorna za to kako se dijete osjeća i kako napreduje”, „Majka mora znati ispuniti sve djetetove potrebe". S obzirom na to da takvim pravilima nije moguće udovoljiti, nakon rođenja djeteta uvidjela je nesklad između svojih očekivanja i realiteta, potencirano žuticom i učestalim plačem djeteta. To je protumačila kao dokaz svoje neadekvatnosti kao majke (,Zato što nisam stalno sretna zbog djeteta, nisam normalna majka”, „Poslijeporođajna depresija znači da ne volim svoje dijete”, „Postoji jedan ispravan način odgoja djeteta, a ja ga ne znam", „To što mi drugi pomažu dokaz je moje nekompetencije"). $\mathrm{U}$ nošenju s negativnim samoevaluacijama u početku je primjenjivala kompenzacijske strategije pojačanog truda oko sina, uz odbijanje da se nakratko odvoji od njega. Budući da takva ponašanja nisu mogla spriječiti negativne misli te su produbila umor i potištenost, postupno je odustala od njih sve do izbjegavanja djeteta.

\section{Planirane i tijek tretmana}

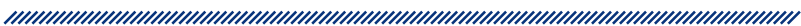

U dogovoru s pacijenticom u terapiju je uveden sertralin u dozi od $50 \mathrm{mg}$, koji je nastavila uzimati bez izraženijih nuspojava kroz šest mjeseci, te je započeta kognitivnobihevioralna terapija.

Ciljevi tretmana bili su usmjereni na povećavanje ugodnih aktivnosti, povećanje uključenosti u brigu oko sina i domaćinstva, povećanje učestalosti socijalnih kontakata, bolje raspoloženje i realističniju procjenu sebe kao majke.
Intervencije: Tijekom deset seansi provedene su intervencije edukacije, samomotrenja, bihevioralne aktivacije, planiranja ugodnih aktivnosti te kognitivnog restrukturiranja.

Među početnim intervencijama provedena je edukacija o depresivnom poremećaju, osobito postpartalnom, uz korištenje primjerima depresivnih majki iz medija, u cilju normalizacije izostanka pozitivnih emocija prema djetetu i pojave negativnih misli o djetetu te smanjenja osjećaja krivnje zbog depresije. U tu svrhu primijenjena je i tehnika racionalno-emocionalnog igranja uloga, $u$ kojoj je prvo terapeut igrao ulogu „racionalnog” dijela svijesti koji vjeruje da je depresija medicinsko stanje za koje pacijentica nije sama odgovorna, a pacijentica „emocionalnog” dijela, koji vjeruje da je sama kriva što si je dopustila da postane depresivna, a potom su uloge zamijenjene.

Budući da je samomotrenje ukazalo na pasivno provođenje vremena u ruminacijama, rano u tretmanu prepoznata je potreba poticanja na bihevioralnu aktivaciju. Pacijentica je navela neke ugodne aktivnosti koje bi mogla primijeniti, no zapreka za njihovo provođenje bilo je nerealistično pravilo da je sebično ako radi nešto ugodno bez djeteta. To pravilo modificirano je u više seansi kroz propitkivanje i bihevioralne eksperimente (npr. motrenje rasta želje za bavljenje djetetom nakon kratkog razdvajanja od njega odlaskom van te motrenje zamora djetetom kada je cijeli dan uz njega; razgovor s prijateljicom koja je potvrdila da svaki dan ima neko vrijeme za sebe). Osim toga, identificirane su neke aktivnosti koje mogu biti ugodne za pacijenticu, a može ih provoditi s djetetom, kao što je šetnja s kolicima. 
Zbog dihotomnih razmišljanja o majčinstvu (,Ako nisam savršena majka, loša sam majka") primijenjena je tehnika kognitivnog kontinuuma, kada su zajednički kreirani opisi potpuno neadekvatne i savršene majke, nakon čega je pacijentica ponavljano poticana na smještanje sebe na kontinuum između ta dva ekstrema. Zbog vjerovanja pacijentice da postoji samo jedan ispravan način skrbi za dijete potražene su informacije o odgoju djece kroz povijest i u različitim kulturama te su razlikovana pravila u odgoju djece koja su apsolutno važna od onih koja su manje važna i podložna su modi i duhu vremena (npr. koliko dugo i često dojiti, podizati dijete na ruke, dozvoliti djetetu da spava s roditeljima i sl.), a oko kojih je učestalo „mozgala” tražeći idealno rješenje. Pomoglo joj je kada je shvatila da je generacija njezine majke imala različita gledišta od aktualnih, a i u aktualnim preporukama u nekim temama nema suglasnosti te postupno prestaje očekivati od sebe „točne” postupke i češće se ponaša „po sluhu”. Prepoznato je da pacijentica ima neke poteškoće u skrbi oko djeteta, ali da je ipak dovoljno dobra u važnim roditeljskim ponašanjima. Poticana je na stalno praćenje i bilježenje situacija u kojima je uspjela samostalno skrbiti oko djeteta, čiji se opseg uz ohrabrivanje terapeuta i supruga postupno povećavao. Modificirano je pravilo da se o djetetu mora brinuti sama, a ako to ne može, bolje da se povuče u potpunosti (također dihotomno) te postupno počinje prepoznavati i preciznije komunicirati o tome koja joj je i kolika tuđa pomoć oko djeteta potrebna. S obzirom na pravila pacijentice o pretjeranoj odgovornosti majke za to kako dijete napreduje i ponaša se primijenjena je tehnika grafičkog prikaza, npr. razloga zašto je dijete nervozno ili plače, što joj pomaže da shvati da je njezina roditeljska vještina važan, ali ne i jedini faktor koji na to utječe.

S pacijenticom je uspostavljen prihvaćajući i suradnički terapijski odnos, koji je stvorio kontekst i za dozirano samootkrivanje terapeuta u vezi s roditeljskim temama.

\section{Ishod i evaluacija}

U razdoblju od tri mjeseca provedeno je deset jednosatnih seansi, dinamikom viđanja svakih deset dana. Tijekom tretmana postupno dolazi do promjene u na bihevioralnom, kognitivnom te afektivnom planu. Prema samoiskazu i opservaciji terapeuta, pacijentica je boljeg raspoloženja, aktivnija, ima doživljaj dovoljne kompetencije za brigu o djetetu, što potvrđuje i suprug. Uz pomoć supruga uglavnom samostalno obavlja poslove u vezi sa sinom, koji dobro napreduje, te vodi brigu o domaćinstvu. Nakon tromjesečnoga psihoterapijskog tretmana nastavljeno je $\mathrm{s}$ kontrolnim pregledima radi praćenja farmakoterapije te se na kontrolnom pregledu šest mjeseci od početka tretmana dogovorno ukida i antidepresiv, a pacijentica izvješćuje da se vratila na posao.

\section{Rasprava i zaključak}

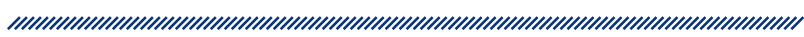

Prikazan je kognitivno-bihevioralni tretman žene s poslijeporođajnom depresijom, provođen usporedo $s$ farmakoterapijskim liječenjem sertralinom u dozi od $50 \mathrm{mg}$. Pacijentica je izražavala želju da bude uključena u psihoterapijski tretman, no s obzirom na to da je ispoljavala kliničku sliku teške depresivne epizode te kako nije dojila, sugerirano je da prihvati i paralelnu primjenu psihofarmaka, zbog očekivanoga bržeg nastupa učinka i u skladu s navodima iz literature ${ }^{10}$. Odabran je inhibitor ponovnog unosa serotonina sertralin, koji se u literaturi opisuje kao učinkovit i dobro toleriran lijek za poslijeporođajnu depresiju ${ }^{20}$. Kognitivno-bihevioralna terapija provedena je po načelima standardnima za depresivni poremećaj, no uz prilagođavanje posebnim temama i uvjetima poslijeporođajnog razdoblja. Najviše pažnje posvećeno je kognitivnom restrukturiranju nerealističnih pravila povezanih s majčinstvom, jer su se prema kognitivnoj konceptualizaciji ove pacijentice pokazala važnima za nastanak i održavanje depresije.

S obzirom na to da je riječ o prikazu jedne pacijentice, koja je paralelno podvrgnuta farmakoterapijskom i psihoterapijskom tretmanu, ne može se zaključiti koja je vrsta intervencije i u kojoj mjeri imala ulogu u postignutom ublažavanju simptoma. Subjektivni dojam same pacijentice jest da joj je najviše pomoglo identificiranje i modificiranje nerealističnih pravila povezanih s majčinstvom. Neke od ovih intervencija u jednostavnijem obliku mogu primijeniti patronažne sestre ili liječnici obiteljske medicine. 


\section{Literatura}

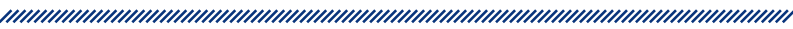

1. Norhayati MN, Nik Hazlina NH, Asrenee AR, Wan Emilin WMA. Magnitude and risk factors for postpartal symptoms: a literature review. J Affect Disord. 2015; 175:34-52.

2. Američka psihijatrijska udruga. DSM-5 Dijagnostički i statistički priručnik za duševne poremećaje. 5. izdanje. Jastrebarsko: Naklada Slap; 2014.

3. Scotish Intercollegiate Gidelines Network. Menagement of perinatal mood disorders: A national clinical guideline. Edinburg: SIGN; 2012. [pristupljeno 15.4.2017.]. Dostupno na:www.sign.ac.uk.

4. Pearlstein T, Howard M, Salisbury A, Zlotnick C. Postpartum depression. Am J Obst Gynecol. 2009; 200(4):357-364.

5. Bernstein IH, Rush AJ, Yonkers K, Carmody TJ, Woo A, McConnell K. Symptom features of postpartum depression: are they distinct?. Depress Anxiety 2008; 25(1):20-26.

6. Hendrick V, Altshuler L, Strouse T, Grosser S. Postpartum and nonpostpartum depression: Differences in presentation and response to pharmacologic treatment. Depress Anxiety. 2000; 11(2):66-72.

7. Canadian Paediatric Society. Maternal depression and child development. Paediatr Child Health 2004; 9(8): 575-582.

8. Ghaedhramati M, Kazemi A, Ebrahimi G, Ebrahimi A, Bahrami M. Postpartum depression risk factors: A narrative review. J Educ Health Promot. 2017; 6:60.

9. Dennis CL, Chung-Lee L. Postpartum depression helpseeking barriers and maternal treatment preferences: $\mathrm{A}$ qualitative systematic review. Birth 2006; 33(4):323-31.

10. Guille C, Newman R, Fryml LD, Liftom CK, Epperson N. Management of postpartum depression.J Midwifery Womens Health. 2013; 58(6):643-653.
11. Fitelson E, Kim S, Scott Baker A, Leight K. Treatment of postpartum depression: clinical, psychological and pharmacological options. Int J Womens Health 2011; 3:1-14.

12. Milgrom J, Danaher BG, Gemmill AW, Holt C, Holt CJ, Seeley $J R$ et al. Internet cognitive behavioral therapy for women with postnatal depression: A randomised controlled trial of MumMoodBooster. J Med Internet Res. 2016; 18(3):e54.

13. Sockol LE. A sistematic review of the efficacy of cognitive behavioral therapy for treating and preventing perinatal depression. J Affect Disord 2015; 177:7-21.

14. Hawton K, Salkovskis PM, Kirk J, Clark DM, ur. Kognitivnobihevioralna terapija za psihijatrijske probleme: Vodič za praktičan rad. Jastrebarsko: Naklada Slap; 2008. 172-236.

15. Sockol LE, Epperson CN, Barber JP. The relationship between maternal attitudes and symptoms of depression and anxiety among pregnant and postpartum first-time mothers. Arch Womens Ment Health 2014; 17(3):199-212.

16. O'Mahen H, Fedrock G, Henshaw E, Himle JA, Forman J, Flynn HA. Modifying CBT for perinatal depression: What do women want? A Qualitative Study. Cogn Behav Pract. 2012; 19:359-371.

17. Hall PL, Wittkowski A. An exploration of negative thoughts as a normal phenomenon after childbirth. J Midwifery Womens Health 2006; 51(5):321-330.

18. Leahy RL, Holland SJ. Planovi tretmana i intervencije za depresiju i anksiozne poremećaje. Jastrebarsko: Naklada Slap; 2000.

19. Beck CT. Postpartum depression: a metasynthesis. Qual Health Res 2002; 12(4):453-472.

20. Stowe ZN, Casarell J, Landry J, Nemeroff CB. Sertraline in the treatment of women with postpartum major depression. Depression.1995; 3(1-2):49-55. 


\section{COMBINED COGNITIVE-BEHAVIOURAL AND PHARMACOLOGIC TREATMENT OF POSTPARTUM DEPRESSION - A CASE STUDY}

1 Marta Gašparović

1 Psychiatry Department, University Hospital Centre Osijek, Osijek

\section{Summary}

Among mental difficulties in the puerperal period, postpartum depression stands out because of its frequency and clinical significance. The cognitive model of postpartum depression stresses the role of specific dysfunctional maternal cognitions, whose content is related to unrealistic idealisation of motherhood, maternal selfefficacy and how they are perceived by others. Due to stressors of parenthood, unrealistic cognitions become activated and lead to the onset and maintenance of depression symptoms.

This case study describes cognitive conceptualisation of the patient who developed postpartum depression after giving birth to her first child, and her treatment, in the duration of 10 sessions, led by principles of cognitive behavioural therapy, combined with pharmacotherapy with sertraline.

Keywords: postpartum depression, cognitive behavioural therapy 